\title{
THE MOBILITY OF THEORY
}

Gavin Lucas

University of Iceland

Department of Archaeology

Sæmundargata 2, 101 Reykjavík, Iceland

gavin@hi.is

Halfway through the second decade of the new millennium, it seems many archaeologists are wondering about the future of their discipline. Perhaps this is a perennial issue, but it does appear - especially in relation to theory - that there is real sense of a sea change happening in archaeology. Such moments typically elicit both negative and positive positions, the former often as a prelude to the latter. Thus one characterization of the current state of archaeological theory is expressed through an attitude of disappointment, boredom even: a perceived lack of real theoretical debate or innovation. Post-processualism has become middle-aged, normalized (Olsen 20I2); there are no great theoretical divides, just a plurality of positions which prefer to join hands rather than fight anymore - "a community of discourses" (Hodder 20I2a). Some archaeologists have even suggested this marks the death of theory altogether - although what they mean more specifically is the death of theoretical paradigms rather than theory per se (Bintliff \& Peirce 20II). For others, however, it rather marks a turning point in our discipline: the context for the birth of a brand new theory, a new paradigm (Olsen 20I2; Kristiansen 20I4). Kristian Kristiansen, in the last keynote for this journal, offered a very positive message (albeit carefully qualified in terms of politics) about just such a new paradigm, one based on a 
scientific revolution connected to new data, not least the potential of aDNA (Kristiansen 20I4). Bjørnar Olsen, in an earlier paper reflecting on the state of archaeological theory, took another tack, promoting a radically different way of seeing archaeology altogether, a view characterized by others as the ontological turn (e.g. Alberti et al. 2013) or a new materialism (Witmore 20I4), and by Olsen himself, as a return to things (Olsen 20IO, 20I2; also see Olsen et al. 20I2).

Although Kristiansen and Olsen's particular visions of the current state of archaeological theory are rather different, they do share one thing in common: they both frame them in terms of a historical perspective and especially one which privileges the idea that archaeological theory somehow advances through major paradigm shifts or revolutions. This is more explicit with Kristiansen but it is still very visible in Olsen's paper. This is not peculiar to them either, but may rather be the dominant way we all tend to think about theory in archaeology - and the way it is taught in university courses. But as Julian Thomas has pointed out, the problem with the paradigm model is that it becomes self-serving; once we view the past history of archaeological theory in this light, the future will inevitably take the same shape (Thomas 2015). We come to expect "the next big thing" in theory. Now that post-processualism feels so dated, we not only anticipate but need another radical shift in theory. The same implicit idea underlies the claim for the death of theory: theory has failed because there has been no new big thing since postprocessualism.

Such arguments highlight the need for a critical reflection on archaeological historiography and the tropes we use to think about theory (or indeed archaeology) in historical perspective. However, rather than try and address this issue head on, I would like to use this critique by Thomas as a springboard for thinking about theory in another way. Specifically, I will shift the register from the historical to the geographical; I will ask questions regarding the location and distribution of theory and, especially, its mobility. And by this I am not referring to centres of theorizing as discussed by Olsen (20I2:I 8-I9), but rather to disciplinary and operational configurations which revolve around the ideas of theory building and theory borrowing. You don't hear much about building theory these days - perhaps it smacks too much of positivism and a Binfordian program (Binford I977a); on the other hand, there is plenty of anxiety around the idea of borrowing theory. In some ways, they represent polar opposites; but I would suggest they are in fact closely intertwined. To explore these two ideas, I want to begin with a kind of fable which illustrates their relationship. 


\section{THE CONTRADICTIONS OF BORROWING}

Recently I was part of a group working on the theme of modern ruins and my particular study looked at an abandoned early 2oth-century fishing village in Iceland (Lucas 20I4; also Olsen \& Pétursdóttir 20I4). Specifically I wanted to examine the processes involved in how this village became a ruin, especially the mobility involved in how things moved along, summed up by the question Where did everything go? In exploring this issue, I drew on theories and ideas from many directions such Hägerstrand's time geography (Hägerstrand 1970) and Wallerstein's commodity chains (Hopkins \& Wallerstein 1986). Now in one sense this represents a classic example of archaeology borrowing theory from outside the discipline - in this case, looking to scholarship in human geography or economic history. But the borrowing is not just confined here.

The more methodological procedures I used during excavation and analysis drew on basic concepts such as stratigraphy and typology which derive from, or at least share ancestry with, geology and natural history. Moreover, not only were theory and method borrowed, so are the very tools I used to practise fieldwork. When I was excavating at the site, we used a total station to record the location of trenches and features, plan and section drawings to record the deposits; surveying technology as we all know, is hardly an archaeological invention and in fact most major developments in this field derive from military contexts, as with so much technology. Even the most basic of archaeological tools, the trowel, was borrowed from the mason's and bricklayer's toolkit. So where does this leave archaeology? Like the proverbial onion, shed of its borrowed traits to reveal ... what? Nothing? Is archaeology second-hand to its core?

Well, I suspect you could play the same game with any discipline, and what it really tells us is that archaeology develops through multiple interactions with a range of other cultural practices, academic and nonacademic. Indeed, to be fair, we should set this game in reverse. Yes, archaeologists may have borrowed the trowel from the mason, but they put it to use in a very different way; not to slap on cement or mortar, but to scrape off soil and dirt; not to build up, but to take down. I should not overplay the oppositions here, though, since the point is rather more general: archaeologists may have borrowed the trowel, but we have also made it our own, exploited its affordances and developed a very different set of techniques - in the Maussian sense - for its operation. The archaeological trowel-in-use is built as much as borrowed. The same applies to methodologies such as stratigraphy - think of the Harris matrix. Surely it must also apply to theory too then? Have I made com- 
modity chains and time geography more "archaeological" in my study? I hesitate on this one. Maybe, maybe not.

Let me leave this question hanging, and take a different tack. What I would like to do now is think about this issue of borrowing and building theory (but especially borrowing) in more general terms and particularly focus in on the source of our anxiety around borrowing, especially in the context of theory. I should say it is an anxiety I have sometimes expressed myself, usually without too much consideration, and so I find this a rather opportune moment to actually spend more time reflecting on the source of this anxiety. Matt Edgeworth has perhaps most recently broached this issue in a call for archaeologists to have more confidence in their engagement with their material as a source of interpretation a source of theory even against the endless introduction of theory from outside archaeology (Edgeworth 20I2).

In thinking about this issue of theory borrowing, one of the first contradictions I encounter is the different way we treat borrowed theory and borrowed methods. Just consider my hesitation earlier about how archaeological my use of time geography really was. After all, you never hear complaints about archaeology borrowing technologies developed elsewhere, from Lidar to radioactive decay. Then there is also the question of whether borrowing is even an appropriate term for a lot of such work in archaeology; the studies on aDNA discussed by Kristiansen - is that archaeologists borrowing theory and techniques from geneticists, or is it just plain collaboration? It seems only with theory do we have this problem of borrowing - such that Olsen felt the need to explicitly pre-empt critics of his position by suggesting that the new materialism is not yet another wave of borrowed theory, but one of real theoretical collaboration (Olsen 20I 2:20). Indeed, Olsen argues it is a rare archaeological moment when other disciplines are actually attuned to a very archaeological sensibility.

Olsen's riposte notwithstanding, it does seem to me that we carry an implicit separation of anxieties when it comes to borrowing on a methodological plane and borrowing on a theoretical plane. Why is that? A flippant response might be that we borrow methods and technologies because they work for us, they have clear implications and consequences for our practice. The primary critique of theory borrowing, on the other hand, revolves around their applicability - or lack of it; so often, theory seems forced onto archaeological data, like a round peg in a square hole. But this characterization is so obvious we should be suspicious. The fact is, all kinds of technologies and methods are considered by archaeologists all the time, that never end up being useful or practical or simply taken up. I remember when a colleague who had worked in Norway 
tried to introduce crescent-shaped hoes (krafsers) into the Cambridge Archaeology Unit when I worked there many years ago - they kind of worked, but were never adopted widely and I am guessing no one uses them now (though I may be wrong!). Flirtation with technology leaves just as many failed relationships as with theory - it is just less visible, possibly because it leaves no trail of published papers.

It seems to me the main reason we are more troubled by borrowing theory than technique relates to an implicit separation we make between data collection and data interpretation and their respective valuations. Data collection as mechanical, interpretation as an art as the heart and soul of archaeology. A lot more is at stake regarding disciplinary identity and significance when it comes to interpretation. Such a valuation runs through the divisions of the digger and the director, the lab technician and the scientist, and even defined the relationship between archaeology and anthropology in the States for a while (e.g. see Deetz I988), archaeology in this instance being defined solely by its methods of data retrieval and analysis, anthropology being the science of interpretation of such data. Of course this separation of data collection and interpretation has been critiqued endlessly for decades now (e.g. Hodder 1999) - but critique does not guarantee its excision from our way of thinking. That is the problem with deepseated prejudices: they have roots which extend much further than we might be aware of.

So if we resist this way of thinking, is it all right to borrow theory then, just as we borrow technique? Should we worry at all? I think the issue is not really about borrowing theory - or technique, but rather the mobility of theorizing. I would like to suggest that what lies at the core of our anxiety around borrowing theory is this question of mobility. I see this expressed in two different ways. One concerns the antagonism to what is often called top-down theorizing - starting not from the evidence or archaeological material itself, but from abstract concepts and ideas. The other concerns the antagonism to imported theorizing - bringing in theories from outside archaeology and applying them to archaeological data. Edgeworth's comments on this matter in his paper cited earlier implicate both of these issues (Edgeworth 20I2). Now the two can be and often are very closely entwined, but I want to separate them here for the purposes of analysis. My aim is to try and deconstruct these anxieties and find out what is it that we find troubling, and how can we rethink the issues involved. Let me begin with the first one. 


\section{TOP-DOWN VS. BOTTOM-UP THEORY}

Top-down theorizing has almost become a dirty word now; instead, we are being increasingly urged to develop bottom-up approaches to archaeology where the archaeological stuff itself is supposed to lead the way. The flaw of a top-down approach is most clearly illustrated in that classic set-up, the case study; a thesis or article outlines a general theoretical position, heavily fortified with extensive citations of thinkers, concepts and other texts, and then proceeds to demonstrate the value of the aforementioned theory with the case study. Essentially, this is also the model we often tell students to follow in their graduate and doctoral research. Sometimes it works, sometimes it doesn't. But the criticism of such an approach often does not seem to be directed at whether it is successful or not; rather it rests - ironically perhaps - on a theoretical presumption that top-down is simply bad. Is the call for a bottom-up approach then simply the new buzz-word or catchphrase? Does it have any real substance?

A very naive reading might simply equate bottom-up with good oldfashioned empiricism; and indeed, this would not be completely off the mark, as the empirical is definitely having a resurgence (e.g. Hillderdal $\&$ Siapkas 2015). Yet there is a difference. The emphasis on a bottomup approach or a critical/radical empiricism - to give it one of its names - is largely being driven not by epistemological concerns but ontological ones. The emphasis on the bottom, is not about archaeological stuff as data, but archaeological stuff as things. What we are being asked to emphasize is the materiality of our data, not its epistemic status. In connection to this, there is the interaction we have with our data. Bottom-up is not just a return to things, it is also a focus on our engagement with them in the context of archaeological practice. In this way, the empirical is not a conceptual realm but a performative one (e.g. Edgeworth 20I2; Olsen et al. 20I2).

Bottom-up is thus also about practice-led research or theory, situating our interpretations within the particular engagement we have with archaeological stuff. Daniel Miller has been very vocal on the advantages of the ethnographic method for conducting research in the social sciences and humanities; he sees real theoretical advantages deriving from such an approach when trying to understand phenomena such as consumption (e.g. Miller 20I2). Some archaeologists are saying the same about our methods. More broadly, much can be gained in reflecting on how other disciplines and practices also engage with things. This is one of the reasons why art has become such a common partner with archaeology over the last decade or so. Indeed, the whole concept of practice- 
led research has largely developed out of traditional art disciplines like design and architecture. Thinking by doing sums it up well.

However, all of this still begs the question: how does a focus on performance and the materiality of archaeological stuff help us develop theory, or interpretation, from the bottom-up? A vicious critic might argue - perhaps justifiably - that this is all a trick. All that is happening is that archaeologists are using another abstract theory - this time about materiality and performance - to interpret archaeological stuff. It remains a top-down approach, masquerading as bottom-up through sheer rhetoric. Indeed, arguably a truly-bottom approach should eschew the whole convention of archaeological writing and rather emphasize alternative, non-representational forms of working. Well, in fact there are examples of such performative archaeology, a project largely initiated by Michael Shanks' work on theatre (Pearson \& Shanks 200I; Shanks 2004) but one which has especially expanded into the realm of visual media (e.g. Cochrane \& Russell 2007; Hamilakis et al. 2009; Hamilakis \& Ifantidis 20I3; Shanks \& Webmoor 20I0; Wickstead 20I3; Russell \& Cochrane 20I4).

Performative and visual archaeologies are exciting developments in our discipline, but they do not in themselves answer the question of how one builds theory from the bottom up - they rather sidestep the whole matter. In a sense, I would argue that to talk about bottom-up theory in any meaningful way means that we need to engage with its evil twin - top-down theorizing. It is difficult to fully explore what we mean by a bottom-up approach without relating it to its opposite and what this actually means. In what way are the two terms set in contrast? Let me turn back the clock now, because I feel there are lessons to be learned from our disciplinary history which may help us answer this question.

\section{MIDDLE-RANGE THEORY REVISITED}

In the I940s, Robert Merton proposed something called middle-range theory in the discipline of sociology (Merton I957). He opposed middlerange theory to total systems theories - those which attempted to unify and encompass the full range of human behaviour or history; such total theories largely harked back to the I8th and I9th centuries - Comte, Marx, Spencer being classic paragons of this method, though it also clear that Merton was also directing his attack at contemporaries like Talcott Parsons who brought Max Weber's brand of sociology into America. For Merton, the problem with such total systems theorizing is that they were too far removed from empirical study in the sense that empirical 
studies could only offer particular instances of the general theory. In a sense, the theory was almost immune from empirical challenge and thus there was little scope for the discipline to actually use empirical studies to develop new theories. Observation was not really being used to generate theory but merely illustrate it.

Merton argued that theory needed to be built up from empirical data; he saw it working in the following way. Day-to-day research involves all kinds of guesses and speculations about what data means; these comprise working hypotheses and are essentially the bottom-level theorizing implied in his scheme. Based on this, scholars construct more rigorous middle-range theories, but these are still fairly local or particular to a certain set or range of phenomena. For Merton, total theories needed to be built up from these; he argued no such total theory had yet been constructed in this way and in fact it was probably still a long time coming. For him, the best exemplars of sociological theory were middle-range.

I was only reading Merton's writing on MRT for the first time recently and what struck me is how contemporary it seems. Building theory from the bottom-up? Re-assembling the social from the ground? These are very familiar arguments, used for example by Latour among many others (Latour 2005). Of course Latour's sociology is starkly different from Merton's, but the broad approach Latour proposes is almost identical. Merton's middle-range theory perhaps never quite had the impact it deserved, though in the I960s the concept was clearly influential in the development of another wave of sociological theorizing called Grounded Theory.

Two sociologists Anselm Strauss and Barney Glaser coined the term in their book from 1967, Glaser being a student of Merton and Strauss, educated within the micro-sociological tradition at Chicago (Glaser \& Strauss 1967; also see Strauss \& Corbin 1994). Their basic approach, based on their research into dying in hospitals, was that data should not be used to test theory but create it - essentially the same idea as Merton's MRT, except that it was developed as an explicit reaction to quantitative methods and the hypothetical-deductive model of positivism. Another difference is that whereas MRT remained fairly general as a description of a certain kind theorizing, GT provided specific guidelines and methods to aid the researcher, including a recursive and reflexive approach to data collection and interpretation. Sounds rather familiar. As a result, GT became a core methodology used by many sociologists, especially in qualitative research and now has a second generation of proponents (e.g. Charmaz 2006).

Now it is MRT rather than GT that has had the bigger impact on archaeology. At the same time though, as archaeologists we all know 
middle-range theory as something a little different to what Merton proposed; as Raab and Goodyear argued in a paper written nearly 30 years ago now, archaeological middle-range theory has come to mean mostly the study of formation processes or perhaps better, the development of bridging arguments between the static nature of the archaeological record and past dynamic processes (Raab \& Goodyear I984). Although Raab and Goodyear were critical of this narrow connotation that MRT came to have in archaeology in contrast to its Mertonian origins, reading Binford's initial use of the term in 1977, there is a clear sense of the Mertonian spirit there - and indeed, the same spirit which was infusing the development of GT around the same time (Binford I977b). Binford distinguished general theory from middlerange theory in his discussion of theory-building in archaeology and argued that the primary imperative facing archaeologists was the development of MRT. Indeed, Binford never really spent much time discussing how to build general theory; his career was largely devoted to explicating and building middle-range theory, especially in the context of hunter-gatherers.

Now we might take exception to the specific way MRT was articulated in archaeology - indeed, in many ways its rather programmatic approach shares much in common with its cousin in sociology GT which was being developed around the same time. GT has in fact also come under criticism for its implicit positivism (e.g. see Thomas \& James 2006). But the underlying philosophy is perhaps what we need to reclaim here and it is this same philosophy, I would suggest, which underpins the current desire to create a bottom-up or practice-led archaeology. But how should we characterize a bottom-up theorizing?

One way is to frame it in terms of that old opposition of theory and data. Thus the original sociological versions of MRT and GT seemed to draw inspiration from a certain naive inductivism - as if theory or interpretation magically emerged from the data, even if methodological guidelines were given about how to develop such theory. More recently though, GT has been squared with both hermeneutic approaches such as ethnographic thick description, as well as more formal post-positivist epistemologies such as abduction or inference to the best explanation (Reichertz 20I0). Such philosophies have of course also been well rehearsed in archaeology too. However, thinking about bottom-up theorizing in this sense is perhaps somewhat misleading. The theory-data opposition is not a very fruitful way to think about bottom-up theorizing; this battle has already been won.

Rather, the bigger and remaining issue is to think about bottom-up theorizing in terms of the opposition of general versus middle-range 
theory. A first question might be: should we see bottom-up theorizing as a route to grander theoretical syntheses or an end in itself? Another way of putting this is in terms of that old distinction between ideographic (i.e. particularizing) vs. nomethetic (generalizing) science and asking which side of this divide archaeology might fall (e.g. Lyman \& O'Brien 2004). However, this divide is itself somewhat artificial and overly dichotomous; as with so many dichotomies, the either/or choice seems somewhat contrived. It is rather both/neither. No, a better way to frame the original question about the relation between general and middle-range theory is to ask whether they constitute two very different types of theorizing - which, I admit, could also be a way to define the distinction between nomethetic and ideographic science, but let's not overcomplicate matters here. What I mean is, is general theory a topdown theory and therefore quite different in approach to middle-range, which is bottom-up - or is general theory just bottom-up theory raised to the power of $n$ ? This latter was in many ways was how Merton saw it, and possibly Binford too. General theory emerges from middle-range theory - it does not come at it from another direction. Indeed, the whole point - then, as perhaps now - is to oppose bottom-up to top-down as two, very different and largely incompatible styles of theorizing. The issue is not whether general theory is possible or not, but how you build it; from the top down, or from the bottom up. The opposition is then not so much between general and middle-range theory, but between styles of theorizing which run in different directions.

After all, the whole point of a bottom-up approach is that we generate or build theory from the data/practice, which implies the generation of multiple theories. General theory then becomes the problem of how to connect these multiple theories together. With a top-down approach, you already start with the assumption that anything covered by the theory is connected. You start with a single theory. The connections pre-exist the data, so to speak. The problem a top-down approach has is connecting the theory to the data. But with a bottom-up approach, the problem is rather different; it is connecting any one theory to another. By this question of connection, I don't mean simply searching for points of common ground, shared theoretical or conceptual perspectives - that we see a lot of these days. I mean actual, interlocking theories where the empirical data in one, connects with that of another in such a way as to actually enhance our understanding of the past, not of our theories. It is a substantive rather than formal connection. It is like constructing an argument or a case where the strength of the argument is bolstered by drawing on multiple, interlocking lines of evidence, only in this case it is a series of different theories or interpretations that are being drawn 
together. But given the blurred line between data and theory, this similarity is surely more than analogical.

One of the consequences of a bottom-up approach to theorizing is, because it starts with specific data of the discipline - in our case, archaeology - bottom-up theorizing is also, by definition, archaeological theory. Again, this is in many ways how Binford and others saw MRT: a distinctly archaeological theory. This is not to say that an archaeological theory must be synonymous with MRT as conventionally understood in archaeology; as Raab and Goodyear pointed out, MRT in the general Mertonian sense is much broader. So by implication, archaeological theory is also broader. We can only equate the two if we broaden our conception of MRT in archaeology.

The question of an archaeological theory being a bottom-up theory, however, raises another issue when juxtaposed against the issue of general theory or synthesis; it is one thing to try and connect two or more archaeological theories or middle-range theories developed through archaeological data, but quite another to connect an archaeological theory to a theory developed in another discipline, which has been generated from different data sets and practices. How commensurable are theories, both within but especially between disciplines, even cognate fields like archaeology and ethnography or history? Such questions lead me to the second of the two features of theorizing I outlined earlier, which concerns the issue of imported theorizing: taking a theory from outside the discipline and working with it in an archaeological context.

\section{IMPORTED THEORY}

Imported theory seems to have this ambiguous status; on the one hand we are all aware of the importance of reading outside our own discipline, that much theoretical inspiration can be obtained by doing so. At the same time, we are also all too aware of many examples of archaeologists citing philosophers and ideas where the connection to archaeology seems all too remote. Then there is the issue of disciplinary hierarchies; how important is archaeology at the academic table next to anthropology, history, or sociology, for example? This is not just about perception but about funding, visibility, relevance and even disciplinary heritage. Of course the academic status of archaeology varies between institutions and countries, but I think it is fair to say that that however archaeology appears to outsiders, many archaeologists have a rather ambivalent attitude towards their own disciplinary identity. I certainly do at times. Arguably, the louder we proclaim our wider academic importance, the 
more we reveal our own insecurity. When you couple this self-imposed inferiority complex about archaeology with the question of imported theorizing, you arrive at the position which suggests that archaeology is always borrowing theory from other disciplines - why can't we reverse this? Why can't we develop theory which anthropology or history will borrow? Why are we always takers and never givers in the arena of social theory? It is difficult to know how real this theory deficit is in archaeology; certainly not everyone agrees with this characterization, either of theory borrowing or our wider academic capital (e.g. Olsen 20I2).

Leaving aside such asymmetries, real or invented, there are different ways to look at cross-disciplinary theorizing. One is simply to see it as a heuristic process, like a trip to a theory supermarket. One browses a broad arena of research in disciplines, whether in search of specific topics or simply to broaden one's horizons. Theories or ideas borrowed from one discipline might be deployed in very specific ways, or they may simply be a useful tool to think with. The latter in particular often tend to circulate quite broadly - thus in our supermarket metaphor, they will be the theories that are the most popular sells this year or decade and indeed have often been critiqued as intellectual fashions or fads (Pluciennik 20II). They circulate among many different disciplines and may even constitute something of a shared body of social theory, although each discipline will of course develop its own discourse around them. Such ideas are what the cultural theorist Mieke Bal has called travelling concepts (Bal 2002).

One of the reasons they travel so widely is that they are concepts without a very clear referent - what the anthropologist Henrietta Moore calls concept-metaphors (Moore 2004, I999). Terms like gender, identity, agency or the self, Moore argues, work because they have a weak ontological commitment and can thus be developed by any number of different disciplines in different ways. They provide a domain within which to think - like a mini-paradigm almost. The problem with them, though, as she also points out, is that their meaning can be constantly shifting and changing. For Moore, this is a positive trait as they maintain ambiguity between universal claims and specific contexts, they keep debate open and keep knowledge moving - gender being a good examplar. In some ways, concept-metaphors dominate archaeological theory today, and indeed have done so for the past thirty years if not longer. They are the post-modern response to the grand theories of the late I9th and early 2oth century - Marxism, structuralism, evolutionism. They also are a vital way of keeping the social sciences and humanities connected without reducing them to within a total system. Moreover, when you think about it, the disciplinary origin of such concepts is often very 
murky, which makes it rather difficult if not misleading to talk about borrowing at all; how is gender a borrowed concept? Indeed, one might even argue the same for some of the grand theories like Marxism - does any discipline have a prior claim on this?

To some extent this is of course all true; but at the same time, these days concepts like gender are almost always discussed within a particular disciplinary framework and while gender may not be borrowed, specific anthropological or sociological etc. theories of gender might be. As such, the direction in which such concepts travel is relevant and for many archaeologists, the concern is that archaeological theories of gender (or whatever concept-metaphor you wish to discuss) seem to rarely travel at all outside its discipline. Again, this concern may be misplaced, and I am not going to argue one way or the other here. Rather I want to juxtapose this notion of disciplines connected by mobile theory, with the notion of a meta-discipline which offers a general theoretical framework. Because this is another way to think about cross-disciplinary theorizing.

I am talking now, of course, of the classic idea of anthropology as the umbrella science of humanity, with its fourfield or manifold subdisciplines one of which is archaeology which might even be traced back as an Enlightenment project (e.g. see Kapferer 2007). The original concept of such an anthropology in many ways included both a bottom-up and top-down approach to theorizing. The bottom-up approach argued that the data generated by the different disciplines such as archaeology and ethnography could be gradually integrated to create a generalizing anthropological theory. However, the very idea of such a generalizing anthropology was coterminous with the top-down theory of cultural or social evolution which provided a pre-existing framework for comparative and cross-cultural analysis. In either case, the opposition of anthropology as a generalizing science and its sub-disciplines working on different data sets, encapsulated the basic philosophical distinction of nomothetic and ideographic science mentioned earlier.

The idea of anthropology as a broader discipline has been recently championed by Tim Ingold (Ingold 2008); needless to say, Ingold's vision of such an anthropology is not the I9th-century version, but rather "an inquiry into the possibilities of human life in the world" (Ingold 2008:88-89). This is a suitably broad yet vague definition, one which nonetheless recognizes the importance of a shared disciplinary space for ethnography and any other field concerned with the study of human beings. At the same time however, if the idea of anthropology is too diluted it risks being somewhat vacuous; is it just a space where all the different disciplines connect up, or is it substantively a true metadiscipline? It seems to me, the difference between the two lies in the par- 
ticular definition we attach to theory as an integrator. What form does integration take? Does it connect or does it synthesize? Should anthropology offer a concrete body of theory, distinct from its sub-disciplines, rather like the distinction of general and middle-range theory? Others would argue for just such a more structured and hierarchical approach to the ur-discipline of anthropology. The anthropologist Roy Ellen, for example, recently posited a three-tier structure to anthropological theory, with Geertzian thick description at the bottom and Darwinian evolutionary theory at the top (Ellen 20I0). This is perhaps not surprising. Darwinism is having a massive resurgence within the social sciences, including archaeology; 20 years ago, it felt as if Darwinian archaeology was a marginal theory, the last twitch of processualism. Today, even Ian Hodder has integrated it into his theory of entanglement (Hodder 20I2b).

However, the problem of such a substantive approach is that it demands a substantive subject. Is it possible to define the subject of anthropology so concretely? Can we talk about a meta-subject for this meta-discipline - which let's face it, essentially means "Mankind" or the human? Since Foucault, since the rise of posthumanism, is there a unitary subject any more to justify the existence of a meta-discipline called anthropology? Or is the human just another concept-metaphor, lacking any concrete referent except in particular disciplinary contexts? And even if it this, is it still a valuable domain within which to think? This is perhaps ultimately what is at stake in this issue: the transformation of humanism from an essentialist idea to a concept-metaphor, a subject with no obvious referent. Arguably, this could be one definition of posthumanism (but see Braidotti 20I3; Wolfe 20I0).

But if we can question the concreteness of the subject of a metadiscipline like anthropology, surely also we can do the same for individual empirical disciplines like archaeology or ethnography. What is the proper subject of archaeology? If we define a discipline like archaeology in terms of its immediate subject, we are presumably talking about material culture, or the archaeological record. But these subjects too are just as slippery as the concept of the human - indeed, most of the ambiguity and ambivalence we feel towards the concept of material culture - a deeply schizophrenic concept if there ever was - can be tied back to the contemporary discourse around posthumanism.

But if we cannot easily define archaeology by its subject, what then? An alternative would be by its practices; indeed this in many ways is how we might also best preserve a sense of disciplinary identity. Moreover, it is our practices which, in a sense, also define or partially constitute our subject. Because we don't simply study the archaeological record - 
we excavate it, we survey it, we photograph it, and so on. We can define the subject or subjects of archaeology or ethnography, but these subjects take on specific characteristics due to the methodological approaches of these disciplines. Practices of excavation or survey, of participant observation or questionnaires actually co-constitute subjects whether these are a Bronze Age barrow or a middle-class consumer. Thinking about archaeology then as a practice also helps us to understand why the term itself has become something of a concept-metaphor for other disciplines. From Freud to Foucault, the idea of archaeology has been a useful concept to think with (Thomas 2004; González-Ruibal 20I3); but like all concept-metaphors, it lacks any single, substantial referent. Its power lies precisely in its ability for flexibility. However, we should be careful to distinguish archaeology as a concept-metaphor from archaeology as set of loosely bundled practices and the status the two have in relation to other disciplines.

However we reflect on this issue, the question of archaeology, of archaeological theory in a sense almost remains the same. Whether we see archaeological theory as derivative of/contributive towards a broader anthropological theory, or whether we see it as just one local articulation of a pool of shared concept-metaphors, it is hard to disconnect archaelogical theory from other disciplines if theory is what we share - what connects us together. In this context, empirically and methodologically, each discipline is unique and distinct, but theoretically, we are family. Even those who suffer from an archaeological inferiority complex and want to reverse the flow of giving and taking, still take this for granted. The very idea that archaeology has something to offer ethnography, cultural geography or sociology presupposes some shared theoretical domain. It seems to me that what matters here is not who takes and who gives, but rather reflecting on what this shared domain is.

Now here comes the twist. Since there is the presumption of a shared theoretical domain - whether this is hierarchically structured or composed of a loose set of concept-metaphors - does this not also imply that there will always be top-down theory of some kind? Let me return to my earlier discussion of bottom-up theory. There, I asked what the status was of general theory; is it developed through top-down theorizing or is it something built up from MRT? I suggested that if we are going to adopt bottom-up theorizing as a model, we have think of general theory in these terms too, not as the product of top-down theorizing. However, where does such bottom-up theorizing ultimately lead, especially in its relation to inter-disciplinary theorizing?

Is it possible that it can only serve to hermetically seal archaeology or indeed any discipline - within its own borders? It is difficult to con- 
ceive how a bottom-up theorizing can ever cross disciplinary borders. Now you might object and say surely different disciplines can be built from the ground up and meet at the top or the middle - like two ends of a tunnel meeting halfway. But consider this: how do they know where to meet? To enable two disciplines to conjoin at all presupposes a shared purpose. And so we are back in the realm of top-down theory.

\section{CONCLUDING REMARKS}

Let me now try and bring my thoughts to a close and return to a core theme motivating this paper: the source of theory in archaeology. I began with a parable about the role of borrowing in archaeology and suggested the issue was not borrowing per se, but the mobility of theorizing. I then analysed this in terms of the critique of two common forms of archaeological theorizing: top-down and imported. I have ended at a point where I suggested top-down theorizing was impossible to avoid so long as we want to maintain some kind of shared disciplinary space with other fields - no matter how loose that space might be defined. But is this really the case? Indeed, are bottom-up and top-down theorizing as mutually exclusive as I have discussed in this paper? Are they even two distinct processes or is it simply the same thing seen from a different perspective?

Let me illustrate this point by comparing the ideas of concept-metaphor to middle-range theory. The idea of concept-metaphor was that it presented theorizing as the working through of a vague and ambiguous concept in the context of specific data. That is, concept-metaphors have no purchase unless they are articulated through specific contexts. Is this not just another version of middle-range theory, where empirical observations are structured through low level interpretation? Is the difference simply one of stress - on concept or observation respectively? After all, concept-metaphors also destabilize and antagonize grand and total theories just as much as middle-range theory did. If this is the case, then surely any specifically archaeological theory or archaeology projected as a source of theory is unlikely to be pure, simply because archaeology is always already hybrid. If we grant all this, in what meaningful sense then can we talk about a specifically archaeological theory?

First, theory is not a thing, a collection of ideas or set of concepts but a process. We need to emphasize the practice of theorizing over theory. Implicit in this is then also the rejection of the opposition of theory and practice, a commonplace enough statement these days. In stressing the idea of theory as a practice, of archaeological theory as a practice, I be- 
lieve we also have a way to answer a paradox which is another way of framing the anxiety around borrowing: why has the idea of archaeology been such a fruitful source of theory or concept-metaphor for other scholars, but at the same time, the practice of archaeology itself seems to always seek theoretical inspiration outside its own field? The point about theorizing as a practice - and perhaps any practice for that matter - is that it is always hybrid. Archaeology cannot be a source of its own theory - not purely so, any more than psychoanalysis can. The paradox arguably highlights a deeper point about the possibility of any theorizing - that it is a blend of concept-metaphors, empirical observations and situated practices. It can occur in an armchair or in the excavation trench. And this takes me to my second point.

Although we can talk about archaeological practice and thus archaeological theorizing, it might be more helpful to think about it in even more localized terms. That is, rather than argue for archaeology as a source of theory, perhaps we should think about excavation as a source of theory, sherd counting as a source of theory, pedagogy as a source of theory - and even theoretical conferences as a source of theory. The advantages of such an approach means that we avoid the hierarchies implied in the disciplinary and epistemological frameworks, where the direction of borrowing and building is always laden with an inherited valuation. In focusing on the practice of theorizing, we flatten everything out. There is no top-down or bottom-up, no trade deficit in the arena of theory.

Whether any of this will dispel our anxieties around these matters I cannot say; there are certainly other issues at stake, including broader academic and institutional politics which themselves connect to deepseated ideologies of knowledge production. However, I do think that if we have confidence in anything, it is in our methods and practices of fieldwork and empirical investigation and so long as we theorize inside these contexts, we will produce archaeological theory of a sort, no matter what other influences we draw on. To what extent such archaeological theorizing will be a source of theory for other disciplines is another matter - but perhaps also one we should let those others worry about.

\section{REFERENCES}

\section{Literature}

Alberti, B., Jones, A. \& Pollard, J. (Eds) 20I3. Archaeology after Interpretation: Returning Materials to Archaeological Theory. Walnut Creek, CA: Left Coast Press.

Bal, M. 2002. Travelling Concepts in the Humanities: A Rough Guide. Toronto: University of Toronto Press. 
Binford, L. (Ed.) I977a. For Theory Building in Archaeology: Essays on Faunal Remains, Aquatic Resources, Spatial Analysis, and Systematic Modelling. New York: Academic Press.

Binford, L. 1977b. General Introduction. In: Binford, L. (Ed.). For Theory Building in Archaeology: Essays on Faunal Remains, Aquatic Resources, Spatial Analysis, and Systematic Modelling. Pp. I-I3. New York: Academic Press.

Bintliff, J. L. \& Pearce, M. (Eds) 20I r. The Death of Archaeological Theory? Oxford: Oxbow.

Braidotti, R. 2013. The Posthuman. Cambridge: Polity.

Charmaz, K. 2006. Constructing Grounded Theory. London: Sage.

Cochrane, A. \& Russell, I. 2007. Visualizing Archaeologies: A Manifesto. Cambridge Archaeological Journal, Vol. I7(I). Pp. 3-19.

Deetz, J. 1988. History and Archaeological Theory: Walter Taylor Revisited. American Antiquity, Vol. 53(I). Pp. I3-22.

Edgeworth, M. 20I2. Follow the Cut, Follow the Rhythm, Follow the Material. Norwegian Archaeological Review. Vol. 45(I). Pp. 76-92.

Ellen, R. 20Iо. Theories in Anthropology and 'Anthropological Theory'. Journal of the Royal Anthropological Institute (N.S.). Vol. 16. Pp. 387-404.

Glaser, B. \& Strauss, A. 1967. The Discovery of Grounded Theory: Strategies for Qualitative Research. New Brunswick: Aldine.

González-Ruibal, A. 2013. Reclaiming Archaeology: Beyond the Tropes of Modernity. London: Routledge.

Hägerstrand, T. 1970. What about People in Regional Science? Papers of the Regional Science Association. Vol. 24(I). Pp. 7-2I.

Hamilakis, Y., Anagnostopoulos, A. \& Ifantidis, F. 2009. Postcards from the Edge of Time: Archaeology, Photography, Archaeological Ethnography (a photo-essay). Public Archaeology. Vol. 8:2-3. Pp. 283-309.

Hamilakis, Y. \& Ifantidis, F. 20I3. The Other Acropolises: Multi-temporality and the Persistence of the Past. In: Graves-Brown, P., Harrison, R. \& Piccini, A. (Eds). The Oxford Handbook of the Contemporary World. Pp. 758-78I. Oxford: Oxford University Press.

Hillerdal, C. \& Siapkas, J. (Eds) 2015. Debating Archaeological Empiricism: The Ambiguity of Material Evidence. London: Routledge.

Hodder, I. 20r2a. Introduction: Contemporary Theoretical Debate in Archaeology. In: Hodder, I. (Ed.). Archaeological Theory Today (2nd edition). Pp. I-I4. Cambridge: Polity.

Hodder, I. 20I2b. Entangled: An Archaeology of the Relationships between Humans and Things. Oxford: Wiley-Blackwell.

Hodder, I. 1999. The Archaeological Process. Oxford: Blackwell.

Hopkins, T. \& Wallerstein, I. 1986. Commodity Chains in the World Economy Prior to I800. Review. Vol. X(I). Pp. I57-I70.

Ingold, T. 2008. Anthropology is Not Ethnography. Proceedings of the British Academy. Vol. 154. Pp. 69-92.

Kapferer, B. 2007. Anthropology and the Dialectic of Enlightenment: A Discourse on the Definition and Ideals of a Threatened Discipline. Australian Journal of Anthropology. Vol. I8. Pp. 72-94. 
Kristiansen, K. 20I4. Towards a New Paradigm? The Third Science Revolution and its Possible Consequences in Archaeology. Current Swedish Archaeology. Vol. 22. Pp. II 34 .

Latour, B. 2005. Reassembling the Social. Oxford: Oxford University Press.

Lucas, G. 20I4. Conduits of Dispersal: Dematerializing an Early Twentieth Century Village in Iceland. In: Olsen, B. \& Pétursdóttir, P. (Eds). Ruin Memories: Materialities, Aesthetics and the Archaeology of the Recent Past. London: Routledge.

Lyman, R. L. \& O’Brien, M. J. 2004. Nomothetic Science and Idiographic History in Twentieth Century Americanist Anthropology. Journal of the History of the Behavioural Sciences. Vol. 40(I). Pp. 77-96.

Merton, T. 1957. Social Theory and Social Structure. New York: Free Press.

Miller, D. 20I2. Consumption and its Consequences. Cambridge: Polity.

Moore, H. 1999. Anthropological Theory at the Turn of the Century. In: H. Moore (Ed.). Anthropological Theory Today. Pp. I-23. Cambridge: Polity Press.

Moore, H. 2004. Global Anxieties, Concept-metaphors and Pre-theoretical Commitments in Anthropology. Anthropological Theory. Vol. 4(I). Pp. 7I-88.

Olsen, B. \& Pétursdóttir, P. (Eds) 20I4. Ruin Memories: Materialities, Aesthetics and the Archaeology of the Recent Past. London: Routledge.

Olsen, B., Shanks, M., Webmoor, T. \& Witmore, C. 20I 2. Archaeology: The Discipline of Things. Berkeley: University of California Press.

Olsen, B. 2010. In Defense of Things: Archaeology and the Ontology of Objects. Lanham, MD: AltaMira Press.

Olsen, B. 20I 2. After Interpretation: Remembering Archaeology. Current Swedish Archaeology. Vol. 20. Pp. II-34.

Pearson, M. \& Shanks, M. 200I. Theatre/Archaeology. London: Routledge.

Pluciennik, M. 20I I. Theory, Fashion, Culture. In: Bintliff, J. \& Pierce, M. (Eds). The Death of Archaeological Theory. Pp. 3I-47. Oxford: Oxbow.

Raab, L. M. \& Goodyear, A. C. I984. Middle-Range Theory in Archaeology: A Critical Review of Origins and Applications. American Antiquity. Vol. 49. Pp. $255^{-268 .}$

Reichertz, J. 20Io. Abduction: The Logic of Discovery of Grounded Theory. Qualitative Social Research. Vol. I I. No. I. Pp. I-I I.

Russell, I. \& Cochrane, A. (Eds) 20I4. Art and Archaeology: Collaborations, Conversations, Criticisms. New York: Springer.

Shanks, M. 2004. Three Rooms: Archaeology and Performance. Journal of Social Archaeology. Vol. 4(2). Pp. I47-I80.

Shanks, M. \& Webmoor, T. 20Io. A Political Economy of Visual Media in Archaeology. In: Bonde, S. \& Houston, S. (Eds). Re-presenting the Past: Archaeology through Image and Text. Pp. 87-I Io. Providence, RI: Brown University Press.

Strauss, A. \& Corbin, J. 1994. Grounded Theory Methodology. In: Denzin, N. K. \& Lincoln, Y. S. (Eds). Handbook of Qualitative Research. Pp. 217-285. Thousand Oaks: Sage Publications.

Thomas, G. \& James, D. 2006. Re-inventing Grounded Theory: Some Questions about Theory, Ground and Discovery. British Educational Research Journal. Vol. 32, 6. Pp. 767-795.

Thomas, J. 2004. Archaeology and Modernity. London: Routledge. 
Thomas, J. 2015. Why Are Archaeologists Discussing "The Death of Archaeological Theory"? In: Hillerdal, C. \& Siapkas, J. (Eds). Debating Archaeological Empiricism. The Ambiguity of Material Evidence. London: Routledge.

Wickstead, H. 20I3. Between the Lines: Drawing Archaeology. In: Graves-Brown, P., Harrison, R. \& Piccini, A. (Eds). The Oxford Handbook of the Archaeology of the Contemporary World. Pp. 549-564. Oxford: Oxford University Press.

Witmore, C. 20I4. Archaeology and the New Materialisms. Journal of Contemporary Archaeology. Vol. I(2). Pp. 203-246.

Wolfe, C. 20I0. What is Posthumanism? Minneapolis: University of Minnesota Press. 